Western University

Scholarship@Western

Aboriginal Policy Research Consortium International (APRCi)

2002

\title{
Substance Abuse Among Urban Aboriginals
}

Kahá:wi J. Jacobs

Kathryn J. Gill

Follow this and additional works at: https://ir.lib.uwo.ca/aprci

Part of the Substance Abuse and Addiction Commons

Citation of this paper:

Jacobs, Kahá:wi J. and Gill, Kathryn J., "Substance Abuse Among Urban Aboriginals" (2002). Aboriginal Policy Research Consortium International (APRCi). 265.

https://ir.lib.uwo.ca/aprci/265 
This article was downloaded by: [University of Western Ontario]

On: 30 October 2012, At: 09:02

Publisher: Routledge

Informa Ltd Registered in England and Wales Registered Number: 1072954

Registered office: Mortimer House, 37-41 Mortimer Street, London W1T 3J H, UK

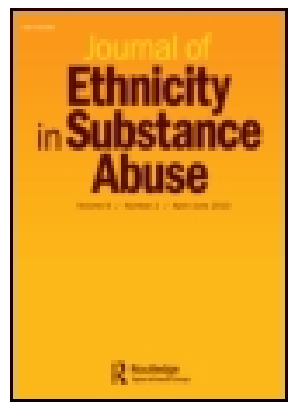

\section{J ournal of Ethnicity in Substance Abuse}

Publication details, including instructions for authors and subscription information:

http:// www. tandfonline.com/loi/ wesa20

\section{Substance Abuse Among Urban Aboriginals}
Kahá: wi J . J acobs MSc ${ }^{a} \&$ Kathryn J. Gill PhD ${ }^{a}$
${ }^{a}$ The Addictions Unit, McGill University Health
Centre and Aboriginal Mental Health Research Team,
Psychiatry Department, McGill University, Montreal,
Quebec, Canada
Version of record first published: 20 Oct 2008.

To cite this article: Kahá:wi J . J acobs MSc \& Kathryn J . Gill PhD (2002): Substance Abuse Among Urban Aboriginals, J ournal of Ethnicity in Substance Abuse, 1:2, 19-39

To link to this article: http:// dx. doi.org/ 10.1300/ / 233v01n02_03

\section{PLEASE SCROLL DOWN FOR ARTICLE}

Full terms and conditions of use: http://www.tandfonline.com/page/termsand-conditions

This article may be used for research, teaching, and private study purposes. Any substantial or systematic reproduction, redistribution, reselling, loan, sub-licensing, systematic supply, or distribution in any form to anyone is expressly forbidden.

The publisher does not give any warranty express or implied or make any representation that the contents will be complete or accurate or up to date. The accuracy of any instructions, formulae, and drug doses should be independently verified with primary sources. The publisher shall not be liable for any loss, actions, claims, proceedings, demand, or costs or damages 
whatsoever or howsoever caused arising directly or indirectly in connection with or arising out of the use of this material. 


\title{
Substance Abuse Among Urban Aboriginals: Association with a History of Physical/Sexual Abuse
}

\author{
Kahá:wi J. Jacobs, MSc \\ Kathryn J. Gill, PhD
}

\begin{abstract}
This paper reports findings of a study of mental health among urban Aboriginal peoples. Both qualitative and quantitative techniques were used to explore the relationship between substance abuse and physical/sexual abuse in a sample of Aboriginal peoples living in an urban community. Open-ended interviews were conducted in a sample of 30 Aboriginals that included Aboriginal social service providers (from health, legal and family services). Forty percent of the sample had been abused and many experienced social, psychological and emotional problems associated with abusive experiences. Content analysis of the interviews revealed common themes in violence discourse including loss of identity and control, the normalization of violence, and revictimization. Substance use, family dysfunction, and difficulty in interpersonal relationships were also associated with abuse experiences.
\end{abstract}

Kahá:wi J. Jacobs and Kathryn J. Gill are affiliated with the Addictions Unit, McGill University Health Centre and Aboriginal Mental Health Research Team, Psychiatry Department, McGill University, Montreal, Quebec, Canada.

Address correspondence to: Kathryn Gill, PhD, Addictions Unit, McGill University Health Centre, 1604 Pine Avenue, West, Montreal, Quebec, H3G 1B4, Canada (E-mail: cz28@musica.McGill.ca).

The authors would like to thank the following individuals for their significant contribution to the completion of this research study: Ms. Natalie Lloyd, Ms. Darlene Wapachee, and Mrs. Ida LaBillois-Montour.

This research was supported by a CQRS (Conseil Quebecois de la Recherche Sociale) team grant to the Aboriginal Mental Health Research Team at McGill University.

Journal of Ethnicity in Substance Abuse, Vol. 1(2) 2002

(C) 2002 by The Haworth Press, Inc. All rights reserved. 
Structured interviews conducted with a larger sample of urban Aboriginals $(n=245)$ revealed high rates of lifetime psychological distress (depression, anxiety, suicidal ideation) as well as attempted suicide (39.1\%). The analyses also demonstrated that there were high rates of sexual abuse (39.6\%), physical abuse (51.8\%) and emotional abuse $(61.6 \%)$ in the sample. When the sample was stratified for history of physical and/or sexual abuse, the analyses indicated that social, psychological and behavioural problems were amplified among those with histories of abuse. Rates of recent and lifetime psychological distress were highest among those who had been both physically and sexually abused. In addition, females were more likely to have been physically and sexually abused (males $25.6 \%$ versus females $48.4 \%$, p < 0.001 ). Family dysfunction was a key indicator of psychological problems among abuse victims. In particular, a family history of psychological problems was strongly associated with physical/sexual abuse. While rates of family history of drug or alcohol problems are high for abused and non-abused individuals alike, those who had experienced physical abuse or physi$\mathrm{cal} /$ sexual abuse rated higher for a current substance abuse problem. It is suggested that issues such as family functioning and the intergenerational transmission of violent behavior and substance abuse be pursued in future mental health research among urban Aboriginal peoples. [Article copies available for a fee from The Haworth Document Delivery Service: 1-800-HAWORTH. E-mail address: < getinfo@haworthpressinc.com> Website: <http://www.HaworthPress.com> () 2002 by The Haworth Press, Inc. All rights reserved.]

KEYWORDS. Aboriginal, urban, interpersonal violence, physical/sexual abuse

\section{INTRODUCTION}

It has been widely acknowledged in writings by Aboriginal peoples (e.g., Brant, 1992; Fox and Long, 2000; ONWA, 1989; Pimadiziwin, 1998) and others (Frohlich et al., 1992; LaPrairie, 1994; LaRocque, 1994; Pelletier and Laurin, 1993; RCAP, 1997) that there are high levels of sexual abuse, family violence and violent death among First Nations peoples. The most prominent victims of family violence are women, teenagers, children and the elderly in Aboriginal and non-Aboriginal communi- 
ties alike (Health Canada, 1994; LaRocque, 1994; RCAP, 1997). Pregnant women have been identified among those with the highest risk for family violence (RCAP, 1997).

According to a Statistics Canada study $(\mathrm{n}=12,300), 30 \%$ of married and previously married women in the ten provinces had been physically or sexually abused by their partners. In addition, $50 \%$ of women experienced some form of physical or sexual violence since the age of 16 (Statistics Canada, 1994). Results of a family violence study conducted by the Ontario Native Women's Association $(\mathrm{n}=104)$ indicated that $84 \%$ of the women surveyed considered family violence to be a problem in their communities and $80 \%$ reported that they had been abused themselves (ONWA, 1989). In addition, 89\% of the women surveyed considered mental and emotional abuse to be a characteristic of family violence in their communities alongside physical abuse (87\%) and sexual abuse $(57 \%)$. Furthermore, the report stated that Aboriginal women were more likely to be abused than non-Aboriginal women ( 1 in 10 non-Aboriginal women, compared to 8 in 10 Aboriginal women) (ONWA, 1989).

The relationship between substance use and abusive behaviours and experiences (including emotional and psychological abuse, neglect, physical and sexual assault, and homicide) is a major concern (Health Canada, 1994). While the association between substance use and family violence had not been thoroughly researched, strong associations between the two were found in a study by Groeneveld and Shain (1989). Based on a sample of 2099 women, results showed that compared to women with no history of abuse, abused women were more likely to use drugs (40\% more used sleeping pills and 74\% more used sedatives) (Groeneveld and Shain, 1989). Petawabano et al. (1994) found that conjugal violence had markedly increased in Aboriginal communities and that $90 \%$ of the situations that required police intervention in one community involved the use of alcohol.

In the U.S., Norton and Manson (1995) conducted secondary analysis of a mental health needs assessment conducted with Aboriginal women $(n=198)$ seeking care at an Indian health centre. Overall, $45.9 \%$ of the women had a history of spousal abuse. Women who reported current spousal assault were significantly more likely to have problems with alcohol $(64.8 \%$ versus $39.2 \%$ of women without a history of spousal abuse, $\mathrm{p}<0.001)$, and alcohol intoxication was associated with the most violent incidents of assault (Norton and Manson, 1995).

The relationship between physical/sexual abuse and alcohol/drug dependence among treatment seekers was further suggested in a study by Gutierres et al. (1994). The study compared male and female urban Ameri- 
can Indian substance abusers on a number of psychological variables including history of abuse. Compared to males, females reported more family dysfunction, family history of substance abuse, and higher rates of childhood emotional, physical and sexual abuse. In all, $84 \%$ of the females said they had been emotionally abused, $74.1 \%$ physically abused and $51.9 \%$ sexually abused, while males reported significantly lower rates in all categories (Gutierres et al., 1994).

Childhood physical/sexual abuse has been associated with substance abuse and psychological problems among non-Aboriginal peoples (e.g., Easton et al., 2000; Langeland and Hartgers, 1998; Spak et al., 1998). Most recently, Easton et al. (2000) found that clients in an outpatient substance abuse treatment facility reported high rates of family history of physical violence $(37 \%)$, physical abuse $(22 \%)$ and childhood abuse $(14 \%)$. In one review, it was shown that compared to people seeking treatment for various medical and social problems, rates of childhood sexual abuse were highest among females seeking treatment for alcoholism (Miller et al., 1993). A study by Robin et al. (1997) demonstrated that there is also a strong relationship between childhood physical/sexual abuse and psychological problems among American Indians. In a sample of 583 Southwestern American Indian tribal members, child sexual abuse and psychiatric disorders were assessed using a semi-structured psychiatric interview. Females were more likely than males to be sexually abused (49\% versus $14 \%$ ) and in $78 \%$ of the cases family members perpetrated the abuse. Sexually abused males and females alike were more likely to report alcohol dependence and behavioural problems. They were also more likely to be diagnosed with three or more psychiatric disorders (Robin et al., 1997). In a later publication, Robin et al. (1998) reported that the majority of both men and women in their study were victims of interpersonal violence (91\%). Of those individuals, $75 \%$ reported that they had been verbally and physically abused. Alcohol was involved in the majority of the violent incidents among males (62\%) and females (74\%) (Robin et al., 1998).

In a recent survey of urban Aboriginal peoples, Jacobs and Gill (2001) found that compared to non-abusers, substance abusers reported significantly higher levels of emotional distress and abuse experiences. In particular, substance abusers reported more suicidal ideation $(61.2 \%$ versus $40.5 \%$ in non-abusers; $\mathrm{p}<.01)$, attempted suicides $(50.7 \%$ versus $22.9 \% ; \mathrm{p}<.01)$ and physical abuse $(65.7 \%$ versus $40.5 \% ; \mathrm{p}<.01)$ in their lifetimes. The strong association between physical/sexual abuse and psychological distress indicated that further research was required to examine this phenomenon. The present study aimed to explore the 
psychological and behavioural characteristics of abused individuals through both open-ended in-depth interviews and structured interviews. Particular attention was paid to the nature and severity of drug or alcohol problems and other psychopathology as well as the characteristics of family and social relationships.

\section{METHODS AND PROCEDURES}

\section{Open-Ended Individual Interviews}

In-depth ethnographic interviews were conducted with urban Aboriginals $(n=30)$. Individuals interviewed included both Aboriginal social service providers (including health, legal and family services) and individuals who used those services. Study participants were recruited through printed advertisements and chain referral. An interview guide was developed to explore support networks, health problems, attitudes toward health and social services, interpersonal violence and problem drug or alcohol use. Information on treatment seeking was gathered for medical problems, violence, and drug and alcohol abuse.

Individual informed consent was obtained from participants to tape record the interviews. Content analysis was performed on the interview data. Analysis involved verbatim transcription of the interviews, a careful review of the transcripts and categorizing the content of the respondents' discourse (Agar, 1996). The Microsoft Word 2000 word processing program was used to index and search the text. Verbatim sections of the text are reproduced and bolded to identify the interviewer's speech, and period marks represent pauses in conversation.

\section{Structured Interviews}

Structured interviews were conducted using the Addiction Severity Index (ASI) (McLellan, 1990) in both English and French versions. The ASI is a structured interview that can be administered by a trained interviewer in approximately 30-40 minutes. It collected a wide range of information, including socio-demographics and assesses problem severity in six areas: drug and alcohol use, family/social functioning, medical status, employment/support, legal status and psychological status. Within each of these problem areas severity was measured in terms of the number, duration, frequency and intensity of symptoms experienced during the past 30 days (McLellan et al., 1990). The interview also collected 
information on the respondents' perceived need for treatment or counseling, the quality of their family and social relationships (e.g., perceived closeness and conflicts with family, friends, neighbours and co-workers) and any history of abuse (in lifetime and preceding 30 days).

The interviews were conducted with 245 status and non-status Native, Métis and Inuit people living in the metropolitan boundaries of the city. Participants were recruited using a number of methods, including: outreach workers who visited targeted parks, drop-in centres, organizations and universities, and advertising the study through a local Native radio station and newspapers. Thus, individuals from many different socioeconomic strata were interviewed, including individuals from $\mathrm{Na}-$ tive-run businesses and organizations, educational institutions, drop-in centres, and from the streets of Montreal. A proportion of the sample includes clients who sought help for problems related to employment/finances, housing, and drug and alcohol problems at the Native Friendship Centre of Montreal.

\section{Statistical Analysis}

Interview data was entered into a database using the scientific software program RS/1 (version 4.3.1 [RS/1, 1991]). The microcomputer version 10.0 of the Statistical Package for the Social Sciences (SPSS, [SPSS, 1999]) was used to perform all statistical analyses. The data was analyzed using Analysis of Variance (ANOVA and MANOVA) for continuous variables and Chi-square tests for categorical variables. Post-hoc tests were performed using t-tests, and in cases where multiple comparisons were conducted on the same set of data, corrections for Type I error were made using a Bonferroni correction.

\section{RESULTS}

\section{Open-Ended Interviews}

The majority of those interviewed were Inuit (26.7\%) (followed by Cree, 20\%; Mohawk, 16.7\%; and Montagnais, 13.3\%) females (77\%). The mean age of the group was $34.4 \pm 1.9$ years. Forty percent of the subjects reported they had experienced some form of abuse in their lifetimes. They reported emotional, physical and sexual abuse by family members, spouses/partners, other children and a grade school teacher. Sixty percent of those abused sought professional help to deal with is- 
sues related to abuse. The service providers interviewed estimated extremely high rates of physical and sexual abuse among clientele who seek social services. One frontline worker approximated that $100 \%$ of the women seeking refuge at a local shelter had experienced some form of abuse in their lifetimes.

Content analysis of transcribed audiotapes revealed common experiences and themes surrounding interpersonal violence. Shared experiences include family dysfunction characterized by male dominance, harsh disciplining, and anger mismanagement. Many reported they had witnessed violence in the home. Subjects also reported experiencing multiple abuses as children and adults, including physical, emotional and sexual assaults. Discourses on abuse histories included the loss of personal identity and loss of control in one's life. One individual who had been sexually abused as a child expressed this difficulty:

... the violence that I've been through from the age 3 to 7 has been through sexual abuse ... I've been raped during that time. As a child? As a child. I don't talk about this part very often but . . . it does make an impact on you. So, and then of course . . . as you grow older, you're really put into a victim stance, you' re not really living life, you're walking around like some sort of zombie ...

A number of the subjects reported experiencing negative psychosocial repercussions of their abuse such as difficulty in interpersonal relationships in adulthood, noting problems with closeness and intimacy. In the words of one person who had been physically and sexually abused as a child:

My mother used to hit me a lot and I think that kind of affected me cause ... I'm afraid of people, and I went through a period of being afraid of my husband that he might hit me and scold me.

For others, the sense of loss teamed with the normalization of violence seemed to establish a pattern for their relationships later in life. Normalization and revictimization were issues for a number of the respondents. In the words of a few individuals,

... myself being abused and going into patterns of relationships, thinking that I was only lovable when I was sexual. There was selfabuse in that sense ... promiscuity and stuff like that. Letting peo- 
ple just do whatever they want with me ... doing things that I didn't wanna do.

He was abusive, my [spouse]. He was abusive? Yeah. In what way? Oh, physically, emotionally, mentally. Very abusive. . . . And ... I was very young ... when I started going out with him. And ... so he pretty much took advantage of me in every way. And I think that ... fathers and mothers are extremely responsible for teaching their children what kind of . . . behaviour they should expect from a potential spouse. .. . And they should teach them that they should be honored and that they deserve to be treated with respect and love. . . . But I wasn't taught that because the example was ... my mom took abuse you know? So for me it was normal.

. . . my 2 oldest [children], they're very angry because I went through a lot, they seen me go through a lot. Being um, physically abused by their father, and then the break up [with] their father, and then me remarrying somebody else, and seeing me go through it again. And they became very angry. They're angry with me, also, which I don't blame them.

Subjects also linked physical and sexual violence with the consumption of alcohol. Under certain circumstances, aggression was considered an expected and on some level acceptable easily excusable consequence of inebriation. In particular, a number of people were indifferent to violence in bars, as can be seen in the following excerpts.

Well I've seen especially in the city, I have seen quite a bit of violence in the bars between First Nations people and White people. That's about it, you know. Nothing really serious. Maybe just punches you know, people throwing punches ...

Well my friends are rarely violent. ... Well, just when they're drinking you get into a fight with your friends but that's about it. That's the only violence but when I'm sober I don't see no violence.

... just mostly just bar room fights . . just stupid, just little skirmishes, yeah. ... [It's] only drinking, it's not real. I don't think so. Well yea, it is real when you get beaten up but when you're sober you forget about it, you know, it's your friend [who you fought with]. 
The link between interpersonal violence and substance use under other conditions, however, was not treated with the same indifference. Two subjects made direct causal links between childhood sexual abuse experiences and the development of a substance abuse problem later in life. Alcohol use was used as a coping mechanism, to quell the psychological distress associated with painful memories of abuse. In the words of one individual,

... being sexually assaulted in high school is the only reason I started drinking as far as I'm concerned. Because before I went to that school, I was only there a year and a half, before I went to that school, nobody in my family drank or take drugs. . . I mean, none of it entered my mind until I had left school due to the reason being sexually assaulted by the teacher and the other students.

For one individual the cyclical nature of physical and sexual abuse and the pain associated with those experiences were clearly illustrated. The individual was abused as a child and later became an abusive adult. The topic was discussed at length. The following are excerpts from that conversation.

Uh, when I was growing up as a teenager I was violent. I went through a very difficult time as a child. I was abused mentally, physically and sexually as a child and um . . . when I got to be a teenager I started beating up my sisters and brother ... . [I've] been trying to work on this for 8 [or so] years, on child abuse. And the ideas are still there. And I say no, it's not right. I'm OK and I don't need to do it. If I do, I'm hurting myself. OK, so you mean that you've abused a child before? I've abused a child, I've abused kids. So I was abused and I then, I [sexually] abused the girls that were younger than me. ... The only thing I've never really done is to make amends to people that, that I've [hurt]. . . . [I've] been in so much pain and I'm scared to make amends to them.

Data from these interviews have shown that a large number of the subjects $(40 \%)$ had experienced varying levels of abuse and high degrees of psychological and emotional distress in their lifetimes. They made strong associations between the incidence of interpersonal violence and the use of substances (primarily alcohol). As well, numerous psychological and social problems were identified as sequelae to histories of physical, sexual and emotional abuse. In light of these results, it was prudent to fur- 
ther explore the psychosocial characteristics of those with and without histories of abuse using quantitative methodology.

\section{Structured Interviews}

\section{Sample Characteristics}

As illustrated in Table 1, the mean age of the sample was $32 \pm .62$ years, the gender distribution revealed a higher proportion of females, and Inuit and Cree peoples predominated. Chi square analysis of nation by gender revealed a significant gender difference (males: "Other" Nations $39.5 \%$, Cree $22.1 \%$, Inuit $17.4 \%$; females: Inuit $36.8 \%$, "Other" Nations $24.5 \%$, Cree $16.1 \%$; $<<0.01$ ). The majority of the sample were unemployed and lived with their family (spouse and children). The sample reported high rates of lifetime psychological distress. Most notably, there were high rates of depression $(55.4 \%)$, anxiety $(55.4 \%)$, suicidal ideation (52.9\%), and attempted suicide (39.1\%). The sample also experienced high rates of sexual abuse (39.6\%), physical abuse $(51.8 \%)$ and emotional abuse $(61.6 \%)$ in their lifetimes.

\section{Physical and Sexual Abuse Stratification}

The entire sample was stratified on history of physical and/or sexual abuse in order to compare groups with and without an abuse history on psychological, family and social relationships, and drug/alcohol abuse. Using variables from the ASI, groups were formed on the basis of a history of lifetime physical or sexual abuse. The groups comprised those who never experienced abuse (no abuse-NA group), those who had a past history of physical abuse (PA) only, and those who had a history of both physi$\mathrm{cal}+\mathrm{sexual}$ abuse, or sexual abuse alone (PSA). Compared to males, females were more likely to have been abused (males: NA 43.0\%, PA $31.4 \%$, PSA $25.6 \%$; females: NA $35.5 \%$, PA $16.1 \%$, PSA $48.4 \%$; $\left.\chi^{2}(2), 13.95, \mathrm{p}<0.001\right)$.

\section{Characteristics of Substance Use}

Table 2 outlines the characteristics of drug and alcohol use among the physical/sexual abuse groups. Over half of all individuals with some history of physical/sexual abuse $(\sim 56 \%)$ reported a current substance abuse problem, compared to $25.6 \%$ of those without an abuse history. In addition, those in the PA and PSA groups experienced more days of 
TABLE 1. Selected Characteristics of General Sample $(n=245)$

\begin{tabular}{|c|c|}
\hline Mean Age ( \pm SEM) & $32.2 \pm .62$ \\
\hline $\begin{array}{c}\text { Gender } \\
\text { Male } \\
\text { Female } \\
\end{array}$ & $\begin{array}{l}35.7 \% \\
64.3 \% \\
\end{array}$ \\
\hline $\begin{array}{l}\text { Nation } \\
\text { Inuit } \\
\text { Cree } \\
\text { Mohawk } \\
\text { Micmac } \\
\end{array}$ & $\begin{array}{l}29.9 \% \\
18.3 \% \\
11.2 \% \\
10.8 \% \\
\end{array}$ \\
\hline $\begin{array}{l}\text { Religion } \\
\text { Protestant } \\
\text { Catholic } \\
\text { Native Spirituality } \\
\end{array}$ & $\begin{array}{l}26.2 \% \\
17.8 \% \\
14.2 \% \\
\end{array}$ \\
\hline $\begin{array}{l}\text { Employment Status } \\
\text { Unemployed } \\
\text { Full Time } \\
\text { Student } \\
\end{array}$ & $\begin{array}{l}39.8 \% \\
24.6 \% \\
20.5 \% \\
\end{array}$ \\
\hline Years of Education ( \pm SEM) & $11.2 \pm .23$ \\
\hline $\begin{array}{l}\text { Living Arrangements } \\
\text { With Spouse \& Kids } \\
\text { Alone } \\
\text { Institution/Homeless }\end{array}$ & $\begin{array}{l}46.7 \% \\
27.5 \% \\
11.1 \% \\
\end{array}$ \\
\hline Satisfied with Living Arrangements & $63.6 \%$ \\
\hline
\end{tabular}

drug or alcohol problems and spent more money on alcohol or drugs in the past 30 days, compared to the NA group.

\section{History of Psychological Problems}

There were significantly higher rates of psychological distress among those with histories of physical and sexual abuse compared to those without (see Table 3 ). There was an increase in rates of lifetime trouble concentrating $\left[\chi^{2}(2)=14.67, p=0.001\right]$, anxiety $\left[\chi^{2}(2)=17.98, p=\right.$ $0.0001]$, depression $\left[\chi^{2}(2)=28.45, p=0.0001\right]$, trouble controlling violent behaviour $\left[\chi^{2}(2)=12.83, p=0.002\right]$, suicidal ideation $\left[\chi^{2}(2)=\right.$ $31.86, p=0.0001]$, and attempted suicide $\left[\chi^{2}(2)=27.38, p=0.0001\right]$ between abuse groups. Rates increase across groups, with the lowest levels displayed by the NA group, and subsequent increases among those who experienced physical abuse (PA) and dual abuse (PSA). One exception was in rates of trouble controlling violent behaviour, where the PA group rated highest, followed by the PSA and NA groups.

Table 3 also shows that there were significant differences in rates of recent (past 30 days) psychological distress between abuse groups. 
TABLE 2. Characteristics of Drug and Alcohol Use by History of Abuse $(n=245)$

\begin{tabular}{|c|c|c|c|}
\hline & NA $(n=92)$ & $\mathrm{PA}(\mathrm{n}=52)$ & $\operatorname{PSA}(n=97)$ \\
\hline $\begin{array}{l}\text { Current Substance Abuse } \\
\text { Problem }\end{array}$ & $25.6 \%$ & $55.8 \%$ & $55.7 \%$ ** \\
\hline $\begin{array}{l}\text { Mean Years Used ( } \pm \text { SEM) } \\
\text { Alcohol } \\
\text { Alcohol to Intoxication } \\
\text { Cannabis } \\
\text { Cocaine } \\
\end{array}$ & $\begin{array}{l}9.2 \pm 1.1 \\
7.1 \pm 1.1 \\
4.6 \pm .83 \\
1.5 \pm .42 \\
\end{array}$ & $\begin{array}{r}11.3 \pm 1.1 \\
9.8 \pm 1.1 \\
6.4 \pm 1.2 \\
1.9 \pm .48 \\
\end{array}$ & $\begin{array}{l}9.4 \pm .80 \\
6.7 \pm .72 \\
6.2 \pm .79 \\
2.1 \pm .42 \\
\end{array}$ \\
\hline \begin{tabular}{|l} 
Mean Days Used Past 30 \\
( \pm SEM) \\
Alcohol \\
Alcohol to Intoxication \\
Cannabis \\
Cocaine \\
\end{tabular} & $\begin{array}{l}4.9 \pm .81 \\
2.8 \pm .70 \\
2.9 \pm .79 \\
1.1 \pm .53 \\
\end{array}$ & $\begin{array}{l}7.9 \pm 1.3 \\
5.2 \pm 1.2 \\
2.9 \pm .99 \\
2.0 \pm .65\end{array}$ & $\begin{array}{l}5.9 \pm .81 \\
3.9 \pm .78 \\
2.8 \pm .70 \\
1.3 \pm .47 \\
\end{array}$ \\
\hline $\begin{array}{l}\text { Mean Number of Days } \\
\text { Experienced Alcohol or Drug } \\
\text { Problems (Past } 30)( \pm \text { SEM) } \\
\end{array}$ & $4.6 \pm 1.5$ & $11.0 \pm 2.4$ & $10.3 \pm 1.7^{* *}$ \\
\hline $\begin{array}{l}\text { Mean Amount of Money Spent } \\
\text { on Alcohol or Drugs } \\
\text { (Past } 30 \text { Days) (SEM) }\end{array}$ & $\$ 98.77 \pm 26.76$ & $\$ 241.94 \pm 52.15$ & $\begin{array}{l}\$ 125.99 \pm \\
30.91^{* *}\end{array}$ \\
\hline $\begin{array}{l}\text { Been Treated for a Drug or } \\
\text { Alcohol Problem in the Past }\end{array}$ & $30.7 \%$ & $42.3 \%$ & $38.5 \%$ \\
\hline
\end{tabular}

${ }^{* *} p<0.05$, corrected for multiple comparisons

Trouble concentrating $\left[\chi^{2}(2)=19.48, p=0.0001\right]$, anxiety $\left[\chi^{2}(2)=\right.$ $11.80, \mathrm{p}=0.003$ ], depression $\left[\chi^{2}(2)=19.25, \mathrm{p}=0.0001\right]$, trouble controlling violent behaviour $\left[\chi^{2}(2)=17.98, p=0.008\right]$, and suicidal ideation $\left[\chi^{2}(2)=8.91, p=0.012\right]$ in the past 30 days were all significantly associated with abuse history. Overall, the levels of current psychological distress (past 30 days) was higher in both the PA and PSA compared to the NA group.

\section{Analyses by Gender}

When analyzing the entire sample stratified by gender (regardless of abuse group classification), there were no significant gender differences in rates of recent or lifetime psychological distress. However, 2-way chi square analyses of psychological problems stratified by gender and abuse history indicated that there were significant differences in rates of lifetime trouble concentrating $\left[\chi^{2}(2)=13.82, p=0.001\right]$, anxiety $\left[\chi^{2}(2)=\right.$ $19.41, \mathrm{p}=0.0001]$, depression $\left[\chi^{2}(2)=22.58, \mathrm{p}=0.0001\right]$, trouble controlling violent behaviour $\left[\chi^{2}(2)=20.91, \mathrm{p}=0.0001\right]$, and suicidal ideation $\left[\chi^{2}(2)=25.98, p=0.0001\right]$ across abuse groups for females as 
TABLE 3. Psychological Problems by History of Abuse $(n=245)$

\begin{tabular}{|c|c|c|c|}
\hline & NA $(n=92)$ & $P A(n=52)$ & PSA $(n=97)$ \\
\hline \multicolumn{4}{|l|}{ Experienced in Lifetime } \\
\hline Trouble Concentrating & $29.3 \%$ & $48.1 \%$ & $56.7 \%$ ** \\
\hline Anxiety & $42.4 \%$ & $48.1 \%$ & $71.9 \%$ ** \\
\hline Depression & $37.0 \%$ & $59.6 \%$ & $75.3 \%$ ** \\
\hline $\begin{array}{l}\text { Trouble Controlling Violent } \\
\text { Behaviour }\end{array}$ & $17.4 \%$ & $42.3 \%$ & $37.1 \%$ ** \\
\hline Suicidal Ideation & $30.4 \%$ & $56.9 \%$ & $71.1 \%$ ** \\
\hline Attempted Suicide & $18.5 \%$ & $46.2 \%$ & $54.6 \%$ ** \\
\hline $\begin{array}{l}\text { Prescribed Medication for a } \\
\text { Psychological Problem }\end{array}$ & $10.9 \%$ & $25 \%$ & $26.8 \%$ \\
\hline \multicolumn{4}{|l|}{ Experienced in Past 30 Days } \\
\hline Trouble Concentrating & $16.3 \%$ & $38.5 \%$ & $45.8 \%$ ** \\
\hline Anxiety & $20.7 \%$ & $32.7 \%$ & $44.2 \%$ ** \\
\hline Depression & $6.5 \%$ & $34.6 \%$ & $26.0 \%$ ** \\
\hline $\begin{array}{l}\text { Trouble Controlling Violent } \\
\text { Behaviour }\end{array}$ & $6.5 \%$ & $25.0 \%$ & $16.7 \%^{* \star}$ \\
\hline Suicidal Ideation & $5.4 \%$ & $11.5 \%$ & $19.8 \%$ ** \\
\hline $\begin{array}{l}\text { Number of times treated for a } \\
\text { psychological problem as an } \\
\text { outpatient (in lifetime) }( \pm \text { SEM) }\end{array}$ & $0.3 \pm .07$ & $0.3 \pm .07$ & $1.0 \pm 0.3^{* \star}$ \\
\hline $\begin{array}{l}\text { Days experienced psychological } \\
\text { problems in past } 30( \pm \text { SEM). }\end{array}$ & $9.8 \pm 1.9$ & $11.3 \pm 1.9$ & $14.2 \pm 1.4$ \\
\hline
\end{tabular}

** $p<0.05$, corrected for multiple comparisons

shown in Table 4. There were significant differences in rates of attempted suicide among abuse groups for both genders [males: $\chi^{2}(2)=$ 9.95, $\mathrm{p}=0.007$; females: $\left.\chi^{2}(2)=19.28, \mathrm{p}=0.0001\right]$.

\section{Family and Social Relationships}

The variables "family history of drug and alcohol problems" and "family history of psychological problems" were created by combining questions on mother's and father's drug and alcohol use and psychological problems. During the ASI interview the respondents were asked if their mothers or fathers had a significant drinking, drug use or psychological problem at some point in their lives that did or should have led to treatment. Similarly, the variable "close relationship with parents" is the result of combining two questions from the ASI. Respondents were 
TABLE 4. Psychological Problems by Gender and History of Abuse $(n=245)$

\begin{tabular}{|c|c|c|c|}
\hline & NA $(n=92)$ & PA $(n=52)$ & $\operatorname{PSA}(n=97)$ \\
\hline \multicolumn{4}{|l|}{ Experienced in Lifetime } \\
\hline $\begin{array}{l}\text { Trouble Concentrating } \\
\text { Males } \\
\text { Females* }\end{array}$ & $\begin{array}{l}37.8 \% \\
23.6 \% \\
\end{array}$ & $\begin{array}{l}48.1 \% \\
48.0 \% \\
\end{array}$ & $\begin{array}{l}59.1 \% \\
56.0 \% \\
\end{array}$ \\
\hline \begin{tabular}{|c|} 
Anxiety $^{*}$ \\
Males \\
Females*
\end{tabular} & $\begin{array}{l}45.9 \% \\
40.0 \% \\
\end{array}$ & $\begin{array}{l}48.1 \% \\
48.0 \% \\
\end{array}$ & $\begin{array}{l}54.5 \% \\
77.0 \% \\
\end{array}$ \\
\hline \begin{tabular}{|c} 
Depression \\
Males \\
Females*
\end{tabular} & $\begin{array}{l}35.1 \% \\
38.2 \% \\
\end{array}$ & $\begin{array}{l}51.9 \% \\
68.0 \% \\
\end{array}$ & $\begin{array}{l}63.6 \% \\
78.7 \% \\
\end{array}$ \\
\hline $\begin{array}{l}\text { Trouble Controlling Vic } \\
\text { Behaviour } \\
\text { Males } \\
\text { Females* }\end{array}$ & $\begin{array}{c}29.7 \% \\
9.1 \%\end{array}$ & $\begin{array}{l}29.6 \% \\
56.0 \%\end{array}$ & $\begin{array}{l}40.9 \% \\
36.0 \%\end{array}$ \\
\hline $\begin{array}{l}\text { Suicidal Ideation } \\
\text { Males } \\
\text { Females* } \\
\end{array}$ & $\begin{array}{l}37.8 \% \\
25.5 \% \\
\end{array}$ & $\begin{array}{l}63.0 \% \\
50.0 \% \\
\end{array}$ & $\begin{array}{l}72.7 \% \\
70.7 \% \\
\end{array}$ \\
\hline $\begin{array}{l}\text { Attempted Suicide** } \\
\text { Males } \\
\text { Females }\end{array}$ & $\begin{array}{l}24.3 \% \\
14.5 \%\end{array}$ & $\begin{array}{l}51.9 \% \\
40.0 \%\end{array}$ & $\begin{array}{l}63.6 \% \\
52.0 \%\end{array}$ \\
\hline
\end{tabular}

$p<0.05$, corrected for multiple comparisons

*significantly different for females only

${ }^{* *}$ significantly different for males and females

asked whether or not they felt they had ever had a close, long-lasting, personal relationship with their mothers or fathers.

Chi square tests revealed a strong association between abuse history and having a close relationship with mothers. As shown in Table 5 the rate of close relationships with mothers decreased across the abuse groups, with the lowest level exhibited by the PSA group $\left(\chi^{2}(2), 10.41, \mathrm{p}<0.005\right)$.

Two-way chi square analyses of family and social relationship variables by gender and abuse history were conducted. Results showed that compared to women in other abuse groups, those in the PSA group were the least likely to report having had a close relationship with their mothers (NA 77.8\%, PA 54.2\%, PSA 45.2\%; $\left.\chi^{2}(2), 13.74, p<0.001\right)$. Conversely, women in the PSA group were significantly more likely to report having serious problems with their mothers (NA 25\%, PA $17.0 \%$, PSA 58\%; $\left.\chi^{2}(2), 12.22, \mathrm{p}<0.002\right)$. In addition, there were significant differences in reporting lifetime problems with spouses between abuse groups for both genders, with the highest rates of problems found among the PA and PSA groups (males: NA 31.3\%, PA 66.7\%, 
TABLE 5. Family and Social Relationships by History of Abuse $(n=245)$

\begin{tabular}{|c|c|c|c|}
\hline & NA $(n=92)$ & $\mathrm{PA}(\mathrm{n}=52)$ & $\operatorname{PSA}(n=97)$ \\
\hline $\begin{array}{l}\text { Marital Status } \\
\text { Single } \\
\text { Married } \\
\end{array}$ & $\begin{array}{l}57.6 \% \\
31.5 \% \\
\end{array}$ & $\begin{array}{l}75.0 \% \\
11.5 \% \\
\end{array}$ & $\begin{array}{l}55.2 \% \\
26.0 \% \\
\end{array}$ \\
\hline $\begin{array}{l}\text { Living with } \\
\text { Family } \\
\text { Alone } \\
\text { Friends } \\
\end{array}$ & $\begin{array}{r}53.3 \% \\
31.5 \% \\
5.4 \% \\
\end{array}$ & $\begin{array}{l}38.5 \% \\
21.2 \% \\
15.4 \% \\
\end{array}$ & $\begin{array}{r}45.4 \% \\
26.8 \% \\
9.3 \% \\
\end{array}$ \\
\hline $\begin{array}{l}\text { Satisfied with Living } \\
\text { Arrangements }\end{array}$ & $75 \%$ & $54 \%$ & $58 \%$ \\
\hline $\begin{array}{l}\text { Currently Living with } \\
\text { Someone with an Alcohol } \\
\text { or Drug Problem }\end{array}$ & $10.6 \%$ & $29.4 \%$ & $20.7 \%$ \\
\hline $\begin{array}{l}\text { Had a Close Relationship with } \\
\text { Mother } \\
\text { Father } \\
\text { Spouse } \\
\text { Friends }\end{array}$ & $\begin{array}{l}71.6 \% \\
45.8 \% \\
77.6 \% \\
82.0 \% \\
\end{array}$ & $\begin{array}{l}62.7 \% \\
42.6 \% \\
75.5 \% \\
73.5 \%\end{array}$ & $\begin{array}{l}48.4 \% \text { ** } \\
46.0 \% \\
75.0 \% \\
80.9 \%\end{array}$ \\
\hline $\begin{array}{l}\text { Had Serious Problems Getting } \\
\text { Along with (in Lifetime) } \\
\text { Mother } \\
\text { Father } \\
\text { Spouse } \\
\text { Friends } \\
\end{array}$ & $\begin{array}{l}41.8 \% \\
38.1 \% \\
37.5 \% \\
22.0 \% \\
\end{array}$ & $\begin{array}{l}48.0 \% \\
41.7 \% \\
69.4 \% \\
26.5 \% \\
\end{array}$ & $\begin{array}{l}66.0 \% \text { ** } \\
48.9 \% \\
71.1 \% \text { ** } \\
44.8 \% \text { ** }\end{array}$ \\
\hline $\begin{array}{l}\text { Family History of } \\
\text { Drug/Alcohol Problems }\end{array}$ & $73.5 \%$ & $77.1 \%$ & $83.1 \%$ \\
\hline
\end{tabular}

${ }^{* *} p<0.05$, corrected for multiple comparisons

PSA 73.7\%; $\% ; \chi^{2}(2), 11.15, \mathrm{p}<0.004$ and females: NA $41.7 \%$, PA $72 \%$, PSA 70.4\%; $\%$; $\left.\chi^{2}(2), 11.47, \mathrm{p}<0.003\right)$. As shown in Figure 1 , there were significant differences in rates of family history of psychological problems among the three physical/sexual abuse groups $\left(\chi^{2}(2), 12.56\right.$, $\mathrm{p}<0.002)$.

\section{DISCUSSION}

This study used both qualitative and quantitative techniques to explore the psychological and behavioural characteristics of abuse survivors in an urban Aboriginal community. Analysis of the in-depth interview data indicated that there were a number of problems shared by abuse victims. These problems include substance abuse, difficulty in interpersonal relationships and family dysfunction. Alcohol abuse was a major problem identified by those who had been abused. Drinking appeared to 
FIGURE 1. Family History of Psychological Problems by Abuse Groups $(n=245 ; p<.01)$

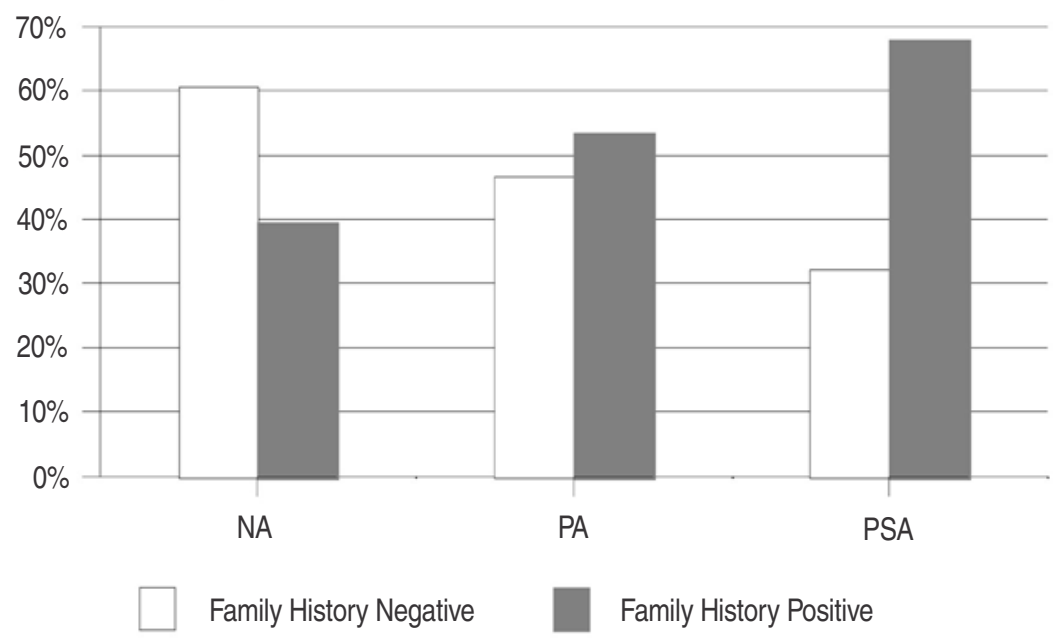

serve as a coping mechanism for early childhood trauma and victimization in adulthood. Common threads woven into the discourse of abuse survivors included loss in terms of identity and control, the normalization of violence, and physical and sexual abuse revictimization.

Abuse and interpersonal violence have been identified as major problems among on- and off-reserve communities (e.g., Pimadiziwin, 1998). Analysis of the structured interviews conducted in the current study would support this impression. There were high rates of abuse in this sample and comparisons between NA, PA and PSA groups on variables for drug and alcohol use, psychological status and family and social relationships revealed a number of problem areas for abuse victims. They were more likely to suffer from psychological distress, to have had relationship problems with their families, and to report a positive family history of psychological problems. In particular, abused females reported significantly more lifetime psychological problems such as depression, anxiety, trouble concentrating, trouble controlling violent behaviour and suicidal ideation. The only exception was that abused males were more likely to have attempted suicide in their lifetimes. Abuse victims were also significantly more likely to report having current problems with substance abuse. As discussed earlier, the relationship 
between childhood physical/sexual abuse and the development of a substance abuse problem later in life is reasonably well established, particularly among women (Langeland and Hartgers, 1998; Miller et al., 1993; Moncrieff et al., 1996; Spak et al., 1998).

It is well acknowledged that a common feature of family violence, crime, and physical/sexual abuse is anger, and the widespread abuse of alcohol and other drugs (Griffiths et al., 1990; Health Canada, 1997). For example, remarking upon the high rates of spousal assault in native communities as well as the disproportionate number of Aboriginals in federal and provincial prisons, Brant (1992) notes that "under the lubricating influence of alcohol ... repressed hostility breaks out into the open and is visited upon innocent bystanders including the spouse, children and neighbours." Brant (1992) also stated that family violence made inroads into Native communities only after the onset of residential schooling, where children were subjected to separation and loss from parents, intimidation, physical beatings and sexual abuse. The onset of family violence linked with alcohol use was made by a respondent in this study. The individual stated that "[when] we lived in the bush it never happened. It's when they started coming more to the urban areas like closer to the city where they had access to alcohol. I never saw that before when we lived in the bush. And then people started drinking and then it was like ... automatic, women were beat up, and sometimes the women were beating up the men, too."

Many studies have indicated that violence and abuse among Aboriginal peoples are consequences of a disadvantaged economic position in society, inadequate housing conditions, lack of or poor quality of services available, loss of traditional culture and government initiatives to eradicate Native cultures (e.g., Brave Heart and DeBruyn, 1998; Griffiths et al., 1987; McEvoy and Daniluk, 1995; Pressman, 1994). It has been proposed that the social disintegration and self-destructiveness apparent among some Aboriginals are a product of chronic trauma and "historical unresolved grief," transmitted across generations (Brave Heart and DeBruyn, 1998). The disadvantaged social position of Aboriginals and the unbalanced historical relationship between the government and Aboriginal peoples are well documented (e.g., Griffiths et al., 1987; Health Canada, 1997). The consequences of neocolonialism have included denial of social status and self-esteem, poverty (in terms of access to resources, education, employment, housing) and sociopolitical subordination (i.e., denial of self-governance) (Griffiths et al., 1987). Family violence is one of the social costs of neocolonialism listed by Griffiths et al. along with family dysfunction (including physical/sexual 
abuse), high rates of suicide and accidental death, as well as crime. Indeed, a study of the effects of childhood abuse among Navajos found that physical abuse and sexual abuse before the age of 15 were risk factors for conduct disorder and alcoholism later in life (Kunitz et al., 1998).

Results from this study are concordant with others in indicating that dysfunctional relationships within the family are a key characteristic for abuse victims. For instance, victims of abuse in this study were significantly more likely than others to report a family history of psychological problems. As well, those in the PSA group were the least likely to report having close relationships with their mothers. High rates of family history of substance abuse problems were found for all groups. A high prevalence of family history of alcoholism was also found among Native Americans with substance abuse problems (Gill et al., 1997; Wall et al., 2000). This is an important issue since untreated abuse has been associated with both an increase in risk for suicide and drug and alcohol use/abuse (Dumont-Smith, 1995). The relationship between parental history of substance abuse, and the development of a substance abuse problem later in life deserves more exploration in future studies of urban Aboriginal peoples.

Issues of traumatic life experiences and posttraumatic stress disorder (PTSD) among alcohol and/or drug dependent populations have become a recent focus in addiction research. For example, Gray (1998) outlined the harmful effects that intergenerationally transmitted trauma can have on the health and well-being of Native peoples. He suggested that early life traumatic events lead to alcohol/drug use as a means of coping and escapism. The substance use and dependence in turn lead to an increased likelihood of experiencing trauma (e.g., interpersonal violence, poor health, poverty, injury) and revictimization (e.g., abusive relationships, prostitution), thus maintaining the cycle. Research has shown that the family plays a key role in transmitting and perpetuating child physical and sexual abuse. It has been estimated that about one third of children who are abused or exposed to violence as children become violent themselves in later life (Wisdom, 1989). Furthermore, sexual abuse revictimization has been associated with a higher likelihood of engaging in a number of sexual activities and unintended or aborted pregnancies (Wyatt et al., 1992).

According to a study by Dumont-Smith and Sioui-Labelle (1991), the three main contributing factors for domestic violence in Aboriginal communities are alcohol/substance abuse, economic problems, and the intergenerational transmission of abuse. It has been suggested that there are a number of barriers to seeking help from available non-Native so- 
cial service agencies including fear of racism and fear of children being apprehended by family services. In addition, some women may not seek help in cases of sexual assault because of bias among authorities in reserve communities, defending the perpetrator (i.e., knowing the perpetrators and disbelieving the women) (e.g., Frank, 1992; LaRocque, 1994; RCAP, 1997).

In summary, the behavioural manifestations of substance use and violence are worthy of further examination. Issues including the quality of family functioning, the intergenerational transmission of violent behaviour, and the efficacy of interventions used to break the cycle of violence also deserve more consideration. In addition, we should also endeavour to refine our understanding of the circumstances surrounding physical and sexual abuse: for instance, further exploration into variables such as the victim's relationship with the perpetrator, the use of force, genital contact, and the timing and context of violence against women, particularly in relation to pregnancy (Ballard et al., 1998; Burnam et al., 1988; Ratican, 1992). Clearly, physical/sexual abuse is both an index of family dysfunction and a predictor for behavioural problems and psychopathology. This makes it an important focus for improving mental and social functioning, and reducing the intergenerational transmission of trauma among urban Aboriginal peoples.

\section{REFERENCES}

Agar MH. 1996. The Professional Stranger: An Informal Introduction to Ethnography. Academic Press Inc., San Diego, CA.

Ballard TJ, Saltzman LE, Gazmaraian JA, Spitz AM, Lazorick S, Marks JS. 1998. Violence during pregnancy: Measurement issues. American Journal of Public Health, 88 (2): 274-276.

Brant C. 1992. Spousal Assault-Anger Management. Healing the Wounds of the Native Family, Highlights of the Conference of the Native Mental Health Association of Canada, September, 1992.

Brave Heart MYH, DeBruyn LM. 1998. The American Indian holocaust: Healing historical unresolved grief. American Indian and Alaskan Native Mental Health Research, 8: 56-78.

Burnam MA, Stein JA, Golding JM, Siegel JM, Sorenson SB, Forsythe AB, Telles CA. 1988. Sexual assault and mental disorders in a community population. Journal of Consulting and Clinical Psychology, 56 (6): 843-850.

Dumont-Smith C. 1995. Aboriginal Canadian children who witness and live with violence. In Peled E, Jaffe PG, Ending the Cycle of Violence: Community Responses to Children of Battered Women, pp. 275-283. Thousand Oaks, CA, USA: Sage Publications.

Dumont-Smith C, Sioui-Labelle P. 1991. National Family Violence Survey: Phase 1. Aboriginal Nurses Association of Canada. 
Easton CJ, Swan S, Sinha R. 2000. Prevalence of family violence in clients entering substance abuse treatment. Journal of Substance Abuse Treatment, 18: 23-28.

Fox T, Long D. 2000. Struggles within the Circle: Violence, healing and health on a First Nations reserve. In, Long, DA, Dickason, OP (eds.), Visions of the Heart: Canadian Aboriginal Issues, pp. 271-301. Toronto: Harcourt Brace Canada.

Frank S. 1992. Family Violence in Aboriginal Communities: A First Nations Report. Victoria, B.C.: Minister of Women's Equality.

Frohlich K, Scott R, Takeda V. 1992. Creating the Montreal Native Family Services for Spousal Assault. Report prepared for the Native Women's Shelter of Montreal.

Gill, K, Eagle Elk, M, Deitrich RA. 1997. A description of alcohol/drug use and family history of alcoholism among urban American Indians. American Indian and Alaska Native Mental Health Research, 8: 41-52.

Gray, N. 1998. Addressing trauma in substance abuse treatment with American Indian adolescents. Journal of Substance Abuse Treatment, 15 (5): 393-399.

Griffiths CT, Glackman W, Esperson T, Davies G. 1990. Programs and Services for Urban Native Indian Alcoholic and Substance Abusers: Initiatives, Outcomes and Issues. British Columbia: Ministry of Labour.

Griffiths CT, Yerbury JC, Weafer LF. 1987. Canadian natives: Victims of socio-structural deprivation? Human Organization, 46 (3): 277-282.

Groeneveld J, Shain M. 1989. Drug Use Among Victims of Physical and Sexual Abuse-A Preliminary Report. Addiction Research Foundation, Toronto. Referenced in: Health Canada (1994).

Gutierres SE, Rousseau NF, Urbanski, L. 1994. Sociocultural and psychological factors in American Indian drug use: Implications for treatment. International Journal of the Addictions, 29: 1761-1786.

Health Canada. 1994. Family Violence and Substance Abuse. The National Clearing House on Family Violence. www.hc-sc.gc.ca/hppb/familyviolence/fvsubab.pdf

Health Canada. 1997. Family Violence in Aboriginal Communities: An Aboriginal Perspective. National Clearinghouse on Family Violence, Ottawa, Ontario. http:// www.hwc.ca/datahpsb/ncfv/nc-cn.htm

Jacobs K, Gill K. 2001. Substance abuse in an urban Aboriginal population: Social, legal and psychological consequences. Journal of Ethnicity in Substance Abuse, in press.

Kunitz SJ, Levy JE, McCloskey J, Gabriel KR. 1998. Alcohol dependence and domestic violence as sequelae of abuse and conduct disorder in childhood. Child Abuse \& Neglect, 22 (11): 1079-1091.

LaPrairie C. 1994. Seen But Not Heard: Native People in the Inner City. Ottawa: Department of Justice, Canada.

LaRocque ED. 1994. Violence in Aboriginal Communities. Reprinted from the book "The Path to Healing" with permission from the Royal Commission on Aboriginal Peoples, Ottawa, Ontario. http://www.hc-sc.gc.ca/hppb/familyviolence/pdfs/vac.pdf

Langeland W, Hartgers C. 1998. Child sexual and physical abuse and alcoholism: A review. Journal of Studies on Alcohol, 59: 336-348.

McEvoy M, Daniluk J. 1995. Wounds to the soul: The experiences of Aboriginal women survivors of sexual abuse. Canadian Psychology, 36: 221-235.

McLellan AT, Parikh G, Braff A et al. 1990. Addiction Severity Index, Administration Manual, 5th ed. Pennsylvania Veterans' Administration Center for Studies of Addiction. 
Miller BA, Downs WR, Testa M. 1993. Interrelationships between victimization experiences and women's alcohol use. Journal of Studies on Alcohol, 11: 109-117.

Moncrieff J, Drummond DC, Checinski K, Farmer R. 1996. Sexual abuse in people with alcohol problems. A study of the prevalence of sexual abuse and its relationship to drinking behaviour. British Journal of Psychiatry, 169: 35-360.

Norton IM, Manson SM. 1995. A silent minority: Battered American Indian women. Journal of Family Violence, 10: 307-318.

ONWA (Ontario Native Women's Association). 1989. Breaking Free: A Proposal for Change to Aboriginal Family Violence. Thunder Bay, Ontario.

Pelletier C, Laurin C. 1993. Assessment of violence and mental health conditions among Native peoples in Quebec. Report prepared for the Quebec Native Women's Association, Centre de recherche et d'analyses en sciences humaines (ssDcc Inc.).

Petawabano BH, Gourdeau E, Jourdain F, Palliser-Tulugak A, Cossette J. 1994. Mental Health and Aboriginal People of Quebec, Le Comite de la Sante Mentale du Quebec, Gaetan Morin, Quebec.

Pimadiziwin. 1998. Highlights of the Pimadiziwin Conference sponsored by the Quebec Native Women Inc., Montreal. See: Healing from a wounded sexuality, pp. 83-85.

Pressman B. 1994. Violence against women: Ramifications of gender, class, and race inequality. In Mirjin MP (ed.) Women in Context: Toward a Feminist Reconstruction of Psychotherapy. New York, NY, USA, Guilford Press.

Ratican KL. 1992. Sexual abuse survivors: Identifying symptoms and special treatment considerations. Journal of Counseling and Development, 71: 33-38.

Robin RW, Chester B, Rasmussen JK, Jaranson JM, Goldman D. 1997. Prevalence, characteristics, and impact of childhood sexual abuse in an Southwestern American Indian tribe. Child Abuse and Neglect, 21: 769-787.

Robin RW, Chester B, Rasmussen JK. 1998. Intimate violence in a Southwestern American Indian tribal community. Cultural Diversity and Mental Health, 4 (4): 335-344.

RCAP (Royal Commission on Aboriginal Peoples). 1997. Minister of Supply and Services, Canada. Ottawa, Ontario.

Spak L, Spak F, Alleback P. 1998. Sexual abuse and alcoholism in a female population. Addiction, 93 (9): 1365-1373.

Statistics Canada. 1994. Wife Assault: The Findings of a National Survey. Juristat Service Bulletin, Canadian Centre for Justice Statistics. Minister of Industry, Science and Technology. Catalogue 85-002.

Wall TL, Garcia-Andrade C, Wong V, Lau P, Ehlers CL. 2000. Parental history of alcoholism and problem behaviours in Native American children and adolescents. $\mathrm{Al}$ coholism: Clinical and Experimental Research, 24: 30-34.

Wisdom C. 1989. Does violence beget violence? A critical examination of the literature. Psychological Bulletin, 106: 3-28.

Wyatt GE, Guthrie D, Notgrass CM. 1992. Differential effects of women's child sexual abuse and subsequent sexual revictimization. Journal of Consulting and Clinical Psychology, 60 (2): 167-173. 